\title{
Gene expression analysis of a murine model with pulmonary vascular remodeling compared to end-stage IPAH lungs
}

\author{
Kayoko Shimodaira 1,2, Yoichiro Okubo ${ }^{1}$, Eri Ochiai ${ }^{3,4}$, Haruo Nakayama' ${ }^{1}$, Harutaka Katano ${ }^{5}$, Megumi Wakayama ${ }^{*}$, \\ Minoru Shinozaki ${ }^{1}$, Takao Ishiwatari ${ }^{1}$, Daisuke Sasai ${ }^{1}$, Naobumi Tochigi ${ }^{1}$, Tetsuo Nemoto ${ }^{1}$, Tsutomu Saji ${ }^{2}$, \\ Katsuhiko Kamei ${ }^{3}$ and Kazutoshi Shibuya, ${ }^{1,6}$
}

\begin{abstract}
Background: Idiopathic pulmonary arterial hypertension (IPAH) continues to be one of the most serious intractable diseases that might start with activation of several triggers representing the genetic susceptibility of a patient. To elucidate what essentially contributes to the onset and progression of IPAH, we investigated factors playing an important role in IPAH by searching discrepant or controversial expression patterns between our murine model and those previously published for human IPAH. We employed the mouse model, which induced muscularization of pulmonary artery leading to hypertension by repeated intratracheal injection of Stachybotrys chartarum, a member of nonpathogenic and ubiquitous fungus in our envelopment.

Methods: Microarray assays with ontology and pathway analyses were performed with the lungs of mice. A comparison was made of the expression patterns of biological pathways between our model and those published for IPAH.

Results: Some pathways in our model showed the same expression patterns in IPAH, which included bone morphogenetic protein (BMP) signaling with down-regulation of BMP receptor type 2, activin-like kinase type 1, and endoglin. On the other hand, both Wnt/planar cell polarity (PCP) signaling and its downstream Rho/ROCK signaling were found alone to be activated in IPAH and not in our model.
\end{abstract}

Conclusions: Activation of Wht/PCP signaling, in upstream positions of the pathway, found alone in lungs from end stage IPAH may play essential roles in the pathogenesis of the disease.

Keywords: Pulmonary Vascular Remodeling, Stachybotrys chartarum, BMP signaling, BMPR2, PCP pathway

\section{Background}

Pulmonary hypertension is a hemodynamic state characterized by elevation of the mean pulmonary arterial pressure leading to right ventricular (RV) failure and premature death. Pulmonary arterial hypertension $(\mathrm{PAH})$ affects the small muscular arteries and arterioles in the lung and is histologically characterized by endothelial and smooth muscle cell proliferation, medial thickening, and thrombosis in situ. Idiopathic pulmonary arterial hypertension (IPAH), one of 6 subcategories

\footnotetext{
* Correspondence: megumi.wakayama@med.toho-u.ac.jp

'Department of Surgical Pathology, Toho University School of Medicine, 6-11-1 Omori-Nishi, Ota-Ku, Tokyo 143-8541, Japan

Full list of author information is available at the end of the article
}

proposed by Dana Point Classification [1], accounts for approximately half of PAH cases [2] and up to $40 \%$ of patients with no family history carries mutations in the bone morphogenetic protein receptor type 2 (BMPR2) gene [1]. $7 \%$ of patients with IPAH has a family history [3], and about $70 \%$ of these have long been recognized and are usually due to mutations in BMPR2, or much less commonly, 2 other members of the transforming growth factor superfamily, activin-like kinase type 1 (ALK1) and endoglin (ENG) [1]. While BMPR2 mutation strongly predisposes to IPAH, only $20 \%$ of mutation carriers develop a clinical disease [4]. This finding suggests that the development of IPAH first requires a genetic susceptibility, followed by one or several secondary

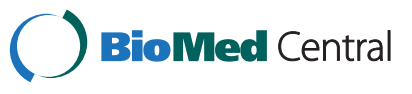


triggering factors such as modifier genes and some sort of stimulus [5]. However, the pathogenesis of IPAH remains unclear.

To elucidate the pathophysiology of IPAH, we conducted genome-wide analysis of RNA expression profiles in lungs obtained from the murine model, which showed a favorable reproducibility to remodel pulmonary arteries induced by inoculation of Stachybotrys chartarum, an ubiquitous fungus in the surrounding environment [6]. This was followed in the study by exploration for factors playing a significant role in the onset of IPAH by searching discrepant or controversial expression patterns between in the model and those in IPAH previously published.

\section{Methods}

Detection of $S$. genes in the human lung tissue of IPAH patients and controls by nested polymerase chain reaction (PCR)

Upon getting the informed consent from patient's family, a part of lung tissue obtained at autopsy from 9 children (under 18 years of age) with IPAH and 9 age-matched controls for detection of $S$. DNA in the tissue of human lung. It had been confirmed that none of them had inflammatory changes or other kind of infection in lungs by histopathological examination before DNA preparation. This protocol was approved by ethical committee of Toho University School of Medicine (\# 20029). Using DNA isolated from the lung tissue, nested PCR and gel electrophoresis were performed in the usual manner. The following primers were used for identification of $S$. gene from autopsied lungs [7,8]: a primary primer of a two-step nested assay, forward primer S-Chart-tri5-F25'-TACACCAGGGAGGAGCGTGTT-3' and reverse primer S-Chart-tri5-R2-5'-GCCGACAATGGT TCGAA GGGA-3' produced a product of $138 \mathrm{bp}$. For the nested PCR primers, forward primer S-Chart-tri5-F2n-5'-GAAA ATCTCCAGTATGCCT- $3^{\prime}$ and reverse primer S-Charttri5-R2n-5'-AGCCTCCAGTCTCTTGGGG-3' produced a product of $96 \mathrm{bp}$. For $\beta$-actin, the control for DNA quality, a two-step nested assay was also used with the following primers: forward primer B3-5'-ACACAACTGTGTT CACTAGC- $3^{\prime}$ and reverse primer B4-5'-CAACTTCATC CACGTTCACC-3' produced a product of $110 \mathrm{bp}$. For the nested PCR primers, forward primer b-globin-nestF34-525 -AACCTCAAACAGACACCAT- $3{ }^{\prime}$ and reverse primer b-globin-nestR103-85-5'-TTGCCCCACAGGGCAGTAA$3^{\prime}$ produced a product of $70 \mathrm{bp}$. The PCR amplification was performed as follows: initial denaturation at $94^{\circ} \mathrm{C}$ for $2 \mathrm{~min}$, followed by 35 cycles of denaturation at $94^{\circ} \mathrm{C}$ for $30 \mathrm{~s}$, annealing at $55^{\circ} \mathrm{C}$ for $30 \mathrm{~s}$, with an extension at $72^{\circ} \mathrm{C}$ for $30 \mathrm{~s}$, and a final extension at $72^{\circ} \mathrm{C}$ for $7 \mathrm{~min}$. The second-round PCR reactions were performed in a manner identical to that applied for the first strand PCR, except for using different sets of primers. The PCR products were analyzed by electrophoresis on an agarose gel stained with ethidium bromide upon preparation.

\section{Fungal preparation and intratracheal injection}

S. chartarum (IFM 53637), which produces trichothecene mycotoxins, was isolated from house dust in Japan, and has been stored in the culture collection of the Medical Mycology Research Center, Chiba University. The fungus was grown on potato dextrose agar (PDA) slants for 3 weeks at $25^{\circ} \mathrm{C}$. Spores were collected in RPMI1640 medium (Sigma, St. Louis, MO, USA) and the concentration was adjusted to $4 \times 10^{5}$ spores $/ \mathrm{ml}$. Spore concentrations and appearance of the suspension were evaluated under light microscopy before use. Sixweek-old male ddY mice (Tokyo Laboratory Animals Science, Tokyo, Japan) were employed in this study. Mice were lightly anaesthetized with an intraperitoneal injection of ketamine $(65 \mathrm{mg} / \mathrm{kg} \mathrm{BW})$ and xylazine $(13 \mathrm{mg} / \mathrm{kg} \mathrm{BW})$. Their mean weight was $27.4 \pm 1.21 \mathrm{~g}$. The mice were placed in a supine position and a $24 \mathrm{G}$ intravascular catheter (Insyte-W; Becton-Dickinson, Sandy, UT, USA) was then inserted intratracheally. The spore suspension $\left(25 \mu \mathrm{l} /\right.$ mouse) containing $1 \times 10^{4}$ spores was injected through the catheter into the trachea of each mouse 12 times at 4-5 day intervals for 8 weeks $(n=3)$ as described previously [6]. Control mice $(n=3)$ were injected with the same volume of RPMI-1640 medium rather than the spore suspension. All mice were cared for in accordance with the rules and regulations set out by the Prime Minister's Office of Japan. Animal protocols were approved by the Special Committee on Animal Welfare of Chiba University. (DOU: 21-65).

\section{Histopathology and morphometric analysis of pulmonary arteries}

Mice were sacrificed using by an overdose of diethyl ether inhalation 7 days after the last injection. Lungs were removed and fixed with a $10 \%$ formaldehyde solution, embedded in paraffin, cut into $3 \mu \mathrm{m}$-thick sections, and stained with hematoxylin and eosin for histopathological examination. Elastic fiber was stained with Elastica-van Gieson staining (Muto pure chemicals, Tokyo, Japan). Morphometric analyses were performed to determine the luminal stenosis of the pulmonary arteries. At least 200 pulmonary arteries per lung section from each mouse were chosen at random and examined. Cross-sections of arteries observed in the section were used to measure the distance between the external elastic lamina, internal elastic lamina, and intravascular lumen. All images were analyzed using IMAGE J 1.36b software (National Institutes of Health, Bethesda, MD, USA). The stricture rate was therefore calculated. Morphometry measurements were performed according 
to the techniques described in Dail and Hammar's Pulmonary Pathology [9]. The thickness of media was calculated by subtracting the distance between the internal elastic lamina from that of the external lamina, and the thickness of the intima was calculated by subtracting the distance between the intravascular lumen from that of the internal elastic lamina. The distance between the external elastic lamina of the artery was defined as the diameter. Arteries were divided into three groups according to diameter: $50<\mu \mathrm{m}, 50-100 \mu \mathrm{m}$, and $>100 \mu \mathrm{m}$. Data are given as mean \pm SD. Statistical analyses were performed using Mann-Whitney's U test. Differences were considered significant at $\mathrm{P}<0.05$.

\section{RNA isolation and quality identification}

RNA was isolated from the whole lung homogenates for both microarray analysis and Real-time (RT) Quantitative PCR with the RNeasy Lipid Tissue Mini Kit (Qiagen, Alameda, CA, USA) according to the manufacturer's instructions and stored at $-80^{\circ} \mathrm{C}$. Total RNA quality was assessed and confirmed using the Agilent Bioanalyzer 2100 (Agilent Technologies, Palo Alto, CA, USA) for visualization of the $28 \mathrm{~S}$ and $18 \mathrm{~S}$ rRNA bands. RNA concentration and purity were also assessed and confirmed using the UV spectrophotometer NanoDrop ${ }^{\text {TM }}$ ND-1000 (NanoDrop Technologies, Wilmington, DE, USA), which calculates $260 / 280$ ratios.

\section{RNA preparation for microarray analysis}

cDNA preparation and microarray analysis were conducted at Bio Matrix Research (Chiba, Japan) using the Affymetrix system (Santa Clara, CA, USA). Isolated total RNA (100 $\mu \mathrm{g})$ was converted into double-stranded cDNA using 3'IVT Express kit (Affymetrix, Santa Clara, CA, USA), which was purified using a GeneChip Sample Cleanup Module (Affymetrix, Santa Clara, CA, USA). In vitro transcription reactions were performed using a GeneChip IVT Labeling Kit, which includes T7 RNA polymerase and biotin-labeled ribonucleotides. Biotinlabeled cRNA was purified using a GeneChip Sample Cleanup Module. The concentration of cRNA was calculated from light absorbance at $260 \mathrm{~nm}$ using a UV spectrophotometer. cRNA (15 mg) was then fragmented at $94^{\circ} \mathrm{C}$ in the presence of a fragmentation buffer (Affymetrix, Santa Clara, CA, USA). The labeled cRNA was purified, fragmented, and spiked with in vitro transcription controls.

\section{Microarray analysis}

Mouse Genome 4302.0 microarrays (Affymetrix, Santa Clara, CA, USA) were hybridized with $12.5 \mu \mathrm{g}$ of cRNA. The array was incubated for $16 \mathrm{hr}$ at $45^{\circ} \mathrm{C}$, and automatically washed and stained with the GeneChip Hybridization, Wash and Stain Kit (Affymetrix, Santa
Clara, CA, USA) on an Affymetrix GeneChip Fluidics station. The arrays were analyzed using the GeneChip Scanner 3000. All preparations were run on qualitycontrolled chips and had $3^{\prime} / 5^{\prime}$ signal ratios of less than 3 . The expression value of the transcript was computed using Affymetrix ${ }^{\circledR}$ GeneChip $\left.{ }^{(}\right)$Command Console ${ }^{\circledR}$ Software (AGCC) with the MAS5 algorithm [10], in which the probabilities of the values of each transcript were indicated as the "Flag" Present ( $p \preccurlyeq 0$ to $<0.04$ ), Marginal ( $\mathrm{p} \preccurlyeq 0.04$ to $<0.06$ ), and Absent ( $\mathrm{s} \preccurlyeq 0.06$ to $<0.5)$. Further analysis was performed with probes that had a present call in all analyzed samples. For analysis, the data were normalized using GeneSpring ${ }^{\circledR}$ GX 10.0 (Agilent Technologies, Palo Alto, CA, USA) data-mining software, per-chip normalization to the 50th percentile of the measurements for the array, and per-gene by normalizing to the median measurement for the gene across all the arrays in the data set. In addition, fold changes were calculated by this software for each gene between the experimental groups and controls. Statistically significant differences were investigated by means of unpaired t-tests. Gene expression differences with $\mathrm{p}<0.05$ and at least a \pm 1.3 -fold change were considered statistically significant. We employed the Biological Networks Gene Ontology (GO) tool BINGO [11] (http://www.psb. ugent.be/cbd/papers/BiNGO) to find statistically overor under-represented GO categories in biologic data as the tool for GO analysis of the stored genes. The analysis was done using the 'hyper geometric test', and all GO biological process terms that were significant with $\mathrm{P}<0.05$ (after correcting for multiple term testing using Benjamin and Hochberg false discovery rate corrections) were selected as over-represented and under-represented. Furthermore, the open access and curated pathway database REACTOME [12] (http://www.reactome.org) was used to determine which events (reactions and/or pathways) were statistically overrepresented in a set of genes.

\section{RT Quantitative PCR for evaluating the microarray results} CDNA preparation and RT-PCR were performed at Bio Matrix Research (Chiba, Japan). $2 \mu \mathrm{g}$ of isolated RNA was used for cDNA synthesis $(40 \mu \mathrm{l})$ using a Superscript III First Strand Synthesis System (Invitrogen, Carlsbad, CA, USA). To evaluate the concentration and purity of cDNA, 260/280 ratios were calculated using the UV spectrophotometer NanoDrop ${ }^{\mathrm{TM}} \mathrm{ND}-1000$ (NanoDrop Technologies, Wilmington, DE, USA). PCR was performed in a $15 \mu \mathrm{l}$ reaction mixture containing $1 \mu \mathrm{l}$ of sample cDNA, $0.75 \mu \mathrm{l}$ of TaqMan ${ }^{\circledR}$ Gene Expression Assays, $7.50 \mu \mathrm{l}$ of TaqMan Universal PCR Master Mix, and $5.75 \mu \mathrm{l}$ of RNase / DNase free water (Applied Biosystems, Foster City, CA, USA). $15 \mu \mathrm{l}$ of PCR reaction mix was transferred into a 384-well reaction plate. The 
primer sequences are given in Table 1. Gene expression was measured on a 7900HT Fast RT-PCR system (Applied Biosystems, Foster City, CA, USA) with cycle conditions of $50^{\circ} \mathrm{C} / 2 \mathrm{~min}, 95^{\circ} \mathrm{C} / 10 \mathrm{~min}, 95^{\circ} \mathrm{C} / 15 \mathrm{sec}$, and $60^{\circ} \mathrm{C} / 1 \mathrm{~min}$ (steps $3-4$ were repeated 40 times). Assay results were collected and analyzed using SDS 2.2 software (Applied Biosystems, Foster City, CA, USA). Each value is the mean of three biological replicates. Data are given as mean \pm SD. Statistical analyses were performed by non-paired t-tests. Differences were considered significant at $\mathrm{P}<0.05$.

\section{Literature search concerning gene expression pattern in IPAH}

We used PubMed (http://www.ncbi.nlm.nih.gov/pubmed/) to search for previous studies published since 2000 that analyzed biological molecules with altered expression using lung samples isolated from IPAH, compared with normal control or secondary PAH. From microarray studies, we referred to open access data stored in Gene Expression Omnibus: GEO (http://www.ncbi.nlm.nih.gov/geo/) and identified the genes that were differentially expressed following the methods described in each study. GO and Pathway analysis were performed on the genes in the same way as we done on our data.

\section{Comparing expression patterns of molecules between IPAH and experimental model}

The biological molecules reported in various studies were collected and divided into groups according to the gene ontology biological process and pathways using the
Gene Ontology Annotation Database GOA [13] (http:// www.ebi.ac.uk/GOA/), REACTOME [12], and KEGG [14] (http://www.genome.jp/kegg/). The expression pattern of each group in IPAH was compared with our PAH models.

\section{Results}

Detection of $S$. genes in human lung tissue from patients with IPAH and controls by nested PCR

S. chartarum DNA was detected in 6 of 9 lung samples among both two groups, children with IPAH and agematched controls (Figure 1). There was no difference in the frequency (approximately 70\%) of the detection in children, with or without of IPAH.

\section{Pathological findings in experimental PAH}

Diffuse symmetric thickening of intima and media in the pulmonary artery was shown in the experimental group (Figure 2). The thickened intima and media were accompanied by proliferation of myointimal and smooth muscle cells, respectively. None of arteries showed alterations corresponding to necrosis, thrombosis, and plexiform lesions. The changes developed in arteries of small and medium-sized were mostly uniform. The thickened intima and media were statistically significant regardless of the size of vessels (Figure 3).

In this model, no venous canals were altered. None were found of components from injected fungus (spores and hyphae) and changes likely induced by the injection, such as perivascular cuffing and intraalveolar inflammatory exudates.

Table 1 Primers used in RT-PCR

\begin{tabular}{|c|c|c|c|}
\hline Gene Symbol & Assay ID* & RefSeq $^{\dagger}$ & Context Sequence \\
\hline Acvrl1 & Mm03053695_s1 & NM_009612.2 & TTTGTGGGAGCACTTGGCCTGTGAC \\
\hline Bmpr2 & Mm01254942_m1 & NM_007561.3 & AGTATACAGATAGGTGAGTCAACAC \\
\hline $\mathrm{Ccl} 8$ & Mm01297184_g1 & NM_021443.2 & CCATGGAAGCTGTGGTITTCCAGAC \\
\hline $\mathrm{Ccl} 9$ & Mm00441260_m1 & NM_011338.2 & AGATCACACATGCAACAGAGACAAA \\
\hline Ear11 & Mm00519056_s1 & NM_053113.2 & CACAACTCCGGCCAGTCATTATTCC \\
\hline Eng & Mm00468256_m1 & NM_001146348.1 & AAAAAACACGTGCAGACTCTCCAGT \\
\hline Gapdh $^{\ddagger}$ & Mm99999915_g1 & NM_008084.2 & TGAACGGATTTGGCCGTATTGGGCG \\
\hline Igj & Mm00461780_m1 & NM_152839.2 & TCCGAATTGTTGTCCCTITGAACAA \\
\hline Mmp12 & Mm00500554_m1 & NM_008605.3 & AAGTITTCAAGGCACAAACCTCTTC \\
\hline Mmp13 & Mm00439495_g1 & NM_008607.1 & GAACCACGTGTGGAGTTATGATGAT \\
\hline Mmp19 & Mm00491300_m1 & NM_021412.1 & TGGTGCTGGGGCCTCGTGGGAAGAC \\
\hline Nos3 & Mm01134921_g1 & NM_008713.4 & CGGCGTGCTGCGGGATCAGCAACGC \\
\hline Pdgfa & Mm01205760_m1 & NM_008808.3 & GGAGGAGGAGACAGATGTGAGGTGA \\
\hline Vegfa & Mm01281449_m1 & NM_001025250.3 & ACGTACTTGCAGATGTGACAAGCCA \\
\hline
\end{tabular}

${ }^{*}$ Taqman ${ }^{(\mathbb{B}}$ Gene Expression Assays.

${ }^{\dagger} \mathrm{NCBI}$ Gene Reference: NCBI transcript ID detected by the assay.

${ }^{\ddagger}$ GAPDH: Glyceraldehyde-3-phosphate dehydrogenase was used as an internal control. 


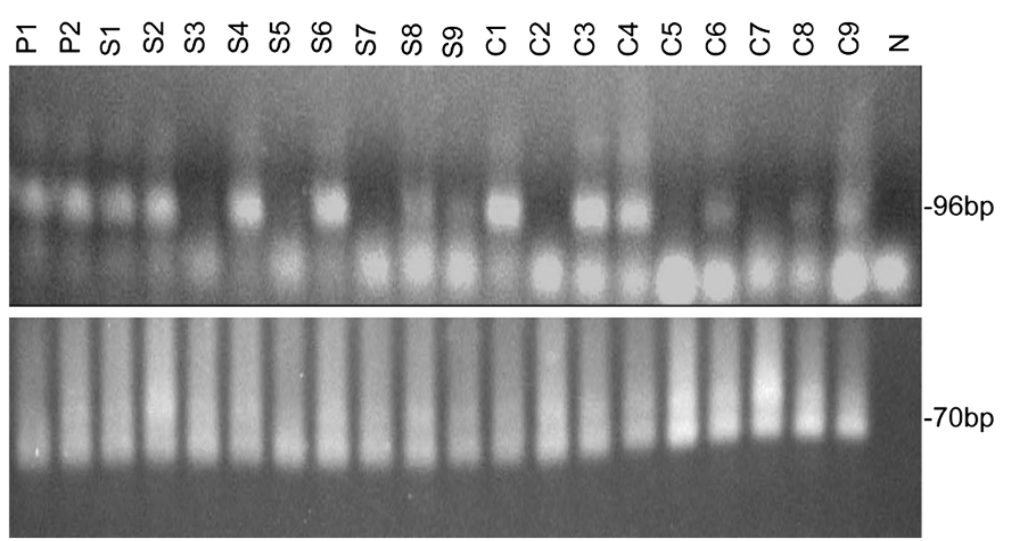

Figure 1 Detection of Stachybotrys chartarum gene in the human lung tissue of IPAH patients and controls. Agarose gel electrophoresis showed the amplification products after nested polymerase chain reaction for S. chartarum DNA using the standard assay. P1- P2: Positive control (96 bp and 70 bp); S1-S9: Children with IPAH; C1-C9: Age-matched control; N: Negative control (No DNA). S. chartarum and $\beta$-globin bands are 96 and 70 bp, respectively. 96 bp-specific band was detectable in P1-2, S1-2, S4, S6, S8-9, C1, C3-4, C6, C8-9.

\section{Gene expression in the PAH model mouse}

Upon normalizing the expression values for the samples, the scatter plot of log intensity values was obtained as shown in Figure 4. 337 and 503 genes were found to exhibit up- and down-regulation from the lungs of mice with inoculation of the fungus in comparison to those from the control group. The most markedly up- and down- regulated genes are shown in Table 2. Down regulation of BMPR2, ALK1, and ENG was found in our PAH model. Down regulation of SMAD family member 6 expression was also observed, while the expressions of other genes involved in bone morphogenetic protein (BMP) signaling were unchanged. All the microarray data are MIAME compliant and the complete microarray data were deposited in GEO (accession number GSE23178). 696 biological process terms were detected by $\mathrm{GO}$ analysis in up-regulated genes. $\mathrm{GO}$ terms related to the immune system and cytokines accounted for about $80 \%$ of total terms. Among the remaining terms, estrogen receptor signaling pathway and serotonin transport/secretion were included. A statistically significant biological process was not found for down-regulated genes. Pathway analysis revealed that reactions and pathways related to the immune system, Janus kinase/signal transducers and activators of the transcription (JAK/ STAT) pathway, and hemostasis etc. were detected (Table 3) in up-regulated genes. Additionally, vascular endothelial growth factor (VEGF), platelet-derived growth factor (PDGF), apoptosis, BMP signaling, etc. were detected in down-regulated genes.

\section{Validation of microarray results by RT quantitative PCR analysis}

RT-PCR was used to validate 14 selected genes that were induced or suppressed by the exposure. The correlation of fold changes in gene expression between the arrays and PCR is shown in Table 4. The results demonstrate completely the same gene expression pattern between both methods. The alterations of gene expressions were statistically significant in BMPR2, ENG, Vascular endothelial growth factor A, Platelet-derived growth factor alpha polypeptide, matrix metallopeptidase (MMP) 19, MMP12, eosinophil-associated ribonuclease A family member 11, and chemokine ligand 9.

\section{Altered expression of biological molecules and genes in lungs from IPAH}

The biological molecules reported in previous studies [15-28] were listed in Additional file 1. Microarray data of patients with IPAH and normal controls were referable from 3 individual studies [15,16,27]. The numbers of IPAH investigated in each study were 2 [16], 7 [27], and 18 [15], the mean age and its standard deviation were $44 \pm 10$ [16], $29 \pm 16$ [27], and $44 \pm 18$ [15], respectively. We analyzed the microarray data in each study and tried to extract the genes that showed common expression patterns through these three studies. However, there were few genes, and none of significant GO or pathways was identified among the previous reports regarding to IPAH.

\section{Comparing expression patterns of molecules between IPAH and experimental model}

Events (reactions and/or pathways) and the expression patterns in IPAH extracted from the previous reports are listed with comparison to those resulted from our experimental model [15-28] (Table 5).

\section{Discussion}

Since PAH is a progressive disease of unknown cause involving pulmonary arterial remodeling, characterized by relentless deterioration and death, intense investigations 


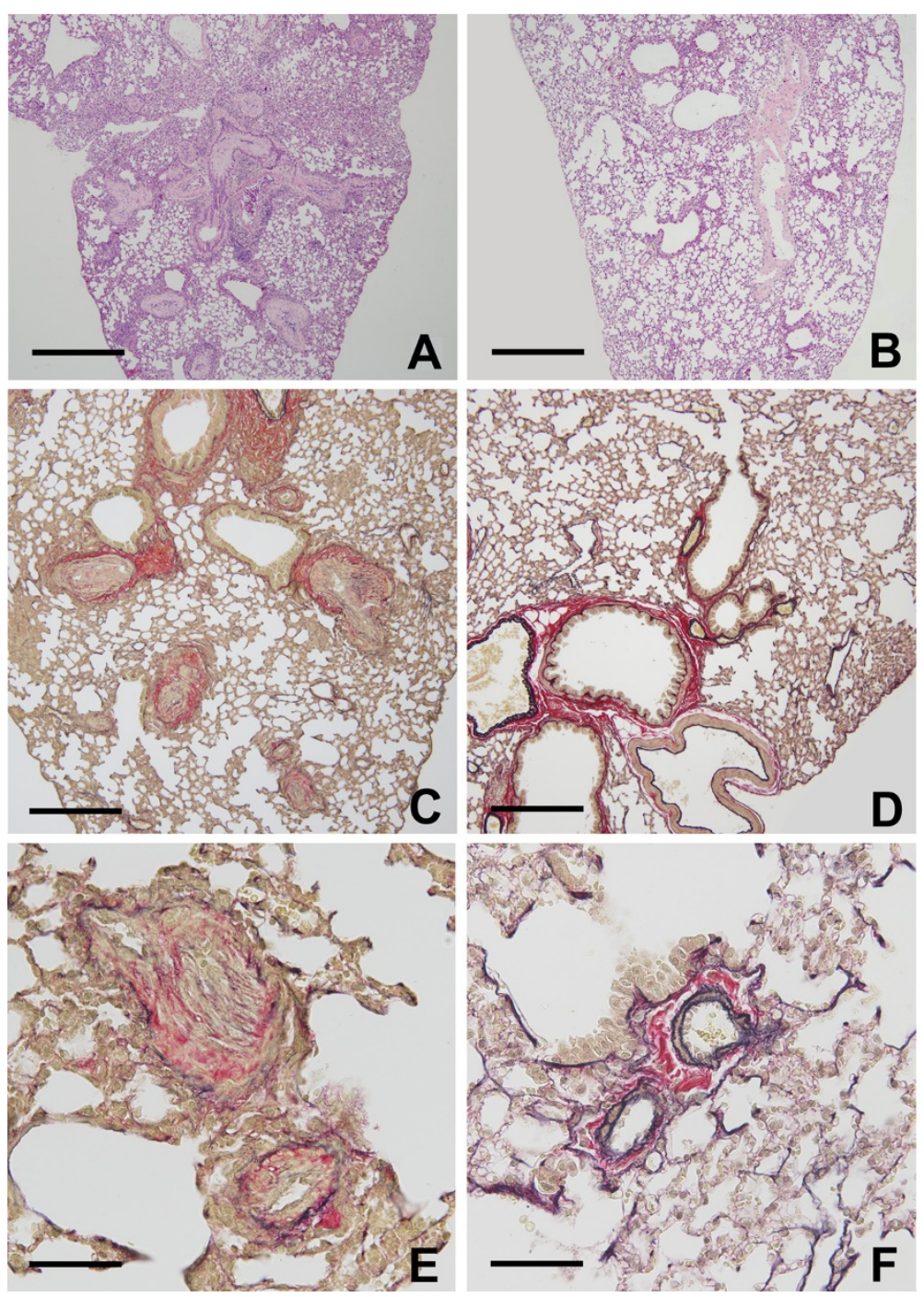

Figure 2 Pulmonary vascular remodeling in Stachybotrys chartarum-exposed mice. Peripheral pulmonary arteries in experimental group $(\mathbf{A}, \mathbf{C}$, and $\mathbf{E})$ and control group (B, D, and $\mathbf{F}$ ). A and B: hematoxylin and eosin double stain, C, D, E, and F: Elastic Van Gieson stain. (A) Pulmonary vascular thickening was present over the whole lung. (C) The arterial wall shows symmetrical thickening of the intima and media. (E) This vascular remodeling almost totally obliterates the lumens. (B, D, and $\mathbf{F})$ Structure of the lung from control group is unaltered. Scale bars: $500 \mu \mathrm{m}(\mathbf{A}, \mathbf{B})$, $250 \mu \mathrm{m}(\mathbf{C}, \mathbf{D})$, and $50 \mu \mathrm{m}(\mathbf{E}, \mathbf{F})$.

have been conducted in a variety of animal models [29] to know pathophysiology. The most commonly used were rats exposed to either hypoxia or monocrotaline, and newer models were introduced that involved modification of these approaches using rodents including transgenic mice $[29,30]$.There were at least three genomewide studies conducting rat models among them, but little have been discussed with comparison to those in the human disease with pathway and GO analyses [31-33]. We have therefore aimed to elucidate a part of pathophysiology of PAH accompanied by pulmonary arterial remodeling with comparison in gene expression pattern between those previously known in end-stage IPAH and our murine model, of which muscularization in media and intima of pulmonary arteries was induced by inoculation of nonpathogenic fungus $[6,34]$. It was found that a large frequency of $S$. chartarum gene in the lung of both children with IPAH and age-matched controls in autopsy cases, whereas the prior histological examination had revealed no inflammatory changes with an association to fungal infection. The result suggests that the airway of human generally exposed by the ubiquitous fungus. Accordingly, unknown intrinsic factors may play a significant role in the onset of IPAH.

It was explored in the study to search the pathways which show common expression pattern among IPAH patients using microarray data previously published as well as up-loaded at the open access sites $[15,16,27]$, but 


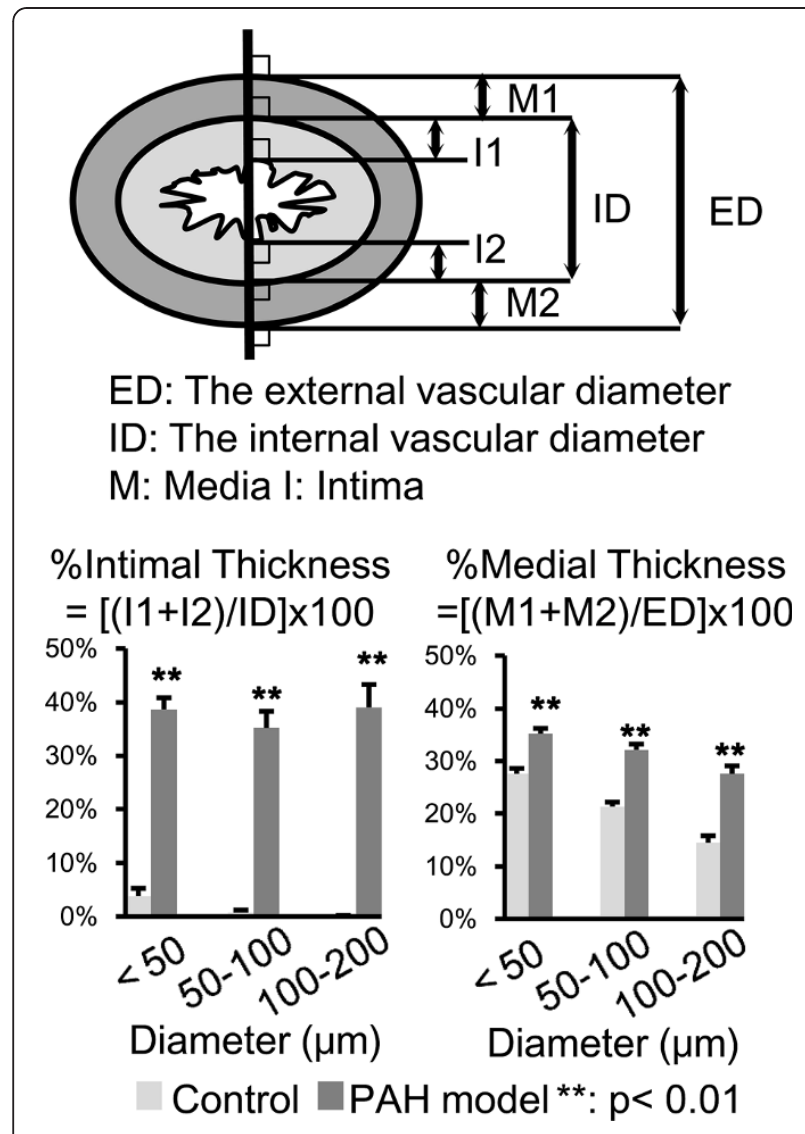

Figure 3 Morphometric analysis evaluating luminal stenosis of pulmonary arteries. Significant thickening of both intima and media were observed in the exposure group when compared with the control regardless of the size of vessels. Data are presented as means with standard error of the means. Statistical analyses were performed using Mann-Whitney's $U$ test. A bar with ** is significantly different $(P<0.01)$.

none were elucidated. A part of the result may reflect clinical differences in subjects such as age, gender, stage of the disease, and etc. On the other hand, the present murine model showed similar expression pattern of genes which has been generally accepted as some biological molecules associated with the pathogenesis of IPAH, such as BMP signaling [1,35,36]: BMPR2, ALK1, and ENG. Although some of previous genome-wide analyses [31-33] conducting rat models reported alterations of signaling pathway (Table 6), the present model revealed more favorable similarity in number of pathways expressing same manner to IPAH. However, the result from our study might be affected by recruited cellular components and/or reformed extracellular matrix, because RNA was extracted from the whole lung of the mice. Although RNA extraction was done one week after the latest inoculation of the fungus when no inflammatory change had been previously confirmed [6], in vitro work evaluating cells from the lungs of the mice

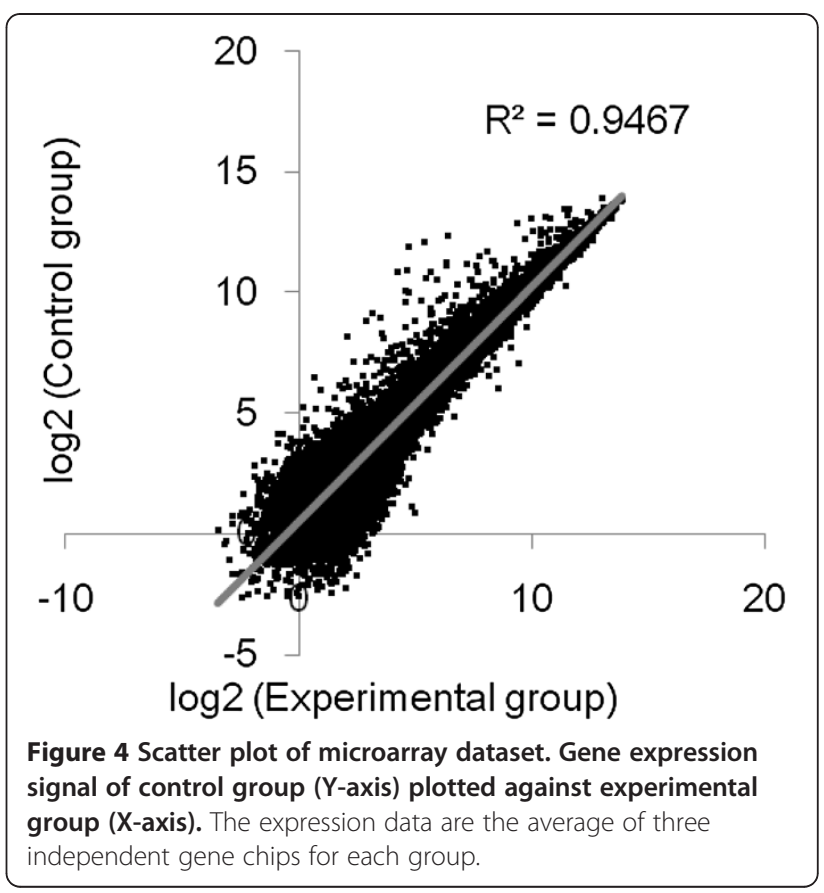

would be required to look at functional alterations. In addition, whereas multiple time point's evaluation could highlight the difference in pathophysiology of models of between our mice and rats previously published, we have evaluated once at the point when the most significant muscularization had been confirmed [6], since a priority in the study would have been set in comparing gene expression patterns between end-stage IPAH and our model. It has been generally accepted that the altered expression of BMP signaling was one of the important molecular reactions when pulmonary vascular remodeling developed as the response to some sort of stimulus $[2,3]$. This can be supported by the facts that only a few cases of BMPR2 mutation carriers developed clinical disease [4] and BMPR2-knockdown mice did not develop pulmonary artery medial hypertrophy, spontaneously [29]. Since remodeling of pulmonary artery in our model may be a sequel to inoculation of nonpathogenic fungus, down regulation of BMPR2 signaling should be simply understood as a consequence of muscularization which might be induced by alteration of signaling pathways at the upper stream. Besides BMP signaling, four more pathways known as identical expression patterns in IPAH were found in our PAH model. It has been suggested that inflammation might participate in the onset and propagation of pulmonary vascular remodeling in PAH via the JAK/STAT pathway $[37,38]$, because elevated levels of inflammatory cytokines could trigger inflammation that is characteristic of PAH of both connective tissue disease-associated [39] and Virusassociated [40]. While PAH is up to threefold more prevalent in women than men [41], the increased 
Table 2 The top 10 most up-regulated and downregulated genes

\begin{tabular}{lll}
\hline $\begin{array}{ll}\text { Fold-Change }^{*} \\
\text { [Up-regulated Genes] }\end{array}$ & Gene Symbol & Description \\
42.4 & Ear11 & $\begin{array}{l}\text { Eosinophil-associated, } \\
\text { ribonuclease A family, member 11 }\end{array}$ \\
46.1 & Mmp12 & Matrix metallopeptidase 12 \\
11.5 & Rgs1 & Regulator of G-protein signaling 1 \\
11.4 & Ccl9 & Chemokine ligand 9 \\
10.3 & Ccl8 & Chemokine ligand 8 \\
10.0 & Igj & Immunoglobulin joining chain \\
9.0 & Igf1 & Insulin-like growth factor 1 \\
8.2 & Gpnmb & Glycoprotein nmb \\
8.2 & Ccl11 & Chemokine ligand 11 \\
8.2 & Ccl22 & Chemokine ligand 22
\end{tabular}

[Down-regulated Genes]

\begin{tabular}{lll}
4.2 & Bex2 & Brain expressed X-linked 2 \\
3.1 & Upk3b & Uroplakin 3B \\
2.9 & Rrm2b & Ribonucleotide reductase M2 B \\
2.7 & Lgals2 & Lectin, galactoside-binding, soluble, 2 \\
2.7 & Acaa1b & Acetyl-Coenzyme A acyltransferase 1B \\
2.3 & Shisa2 & Shisa homolog 2 \\
2.2 & Ssr1 & Signal sequence receptor, alpha \\
2.2 & Kcnip4 & Kv channel interacting protein 4 \\
2.2 & Msln & Mesothelin \\
2.1 & Fam82b & Family with sequence \\
2.1 & & similarity 82 member \\
2.1 & Upk1b & Uroplakin 1B \\
\hline
\end{tabular}

*Fold change values are calculated by dividing the experimental group values by the control values.

expression of molecules associated with the estrogen signaling pathway are reported in both genders of patients with IPAH [15]. In addition, the evidence implicating serotonin has been discussed with correlation to the anorexigenic drugs aminorex and fenfluramine [42]. As with alteration of BMP signaling, the altered expression of these pathways would be simply associated with the consequence of pulmonary vascular remodeling developed as the response to some sort of stimulus. It might be better to understand as a sequel to vascular remodeling because that coagulation activity could be activated by various stimuli such as a cytokine and endothelial dysfunction [43].

On the other hand, it emerged that some discrepant gene expression patterns between those previously known in IPAH and our model. Four pathways were identified as those altered alone in IPAH which comprised up-regulations of the Wnt/planar cell polarity (PCP) signaling pathway [27], the Ras homolog (Rho)/
Table 3 Events (reactions and/or pathways) associated with up-regulated and down-regulated genes

\begin{tabular}{|c|c|c|c|c|}
\hline Event ID* & Event Name ${ }^{\dagger}$ & $P$ value & $\begin{array}{l}\text { Input } \\
\text { Genes in } \\
\text { Event }^{\ddagger}\end{array}$ & $\begin{array}{l}\text { Total } \\
\text { No. of } \\
\text { Genes }^{\S}\end{array}$ \\
\hline \multicolumn{5}{|c|}{ [Up-regulated Genes] } \\
\hline 98458 & Immune System & $1.5 \mathrm{e}-04$ & 24 & 478 \\
\hline 86456 & $\begin{array}{l}\text { Integrin alpha } X \\
\text { beta } 2 \text { binds JAM-C }\end{array}$ & 7.2e-03 & 2 & 6 \\
\hline 108524 & GPCR ligand binding & 3.0e-02 & 13 & 322 \\
\hline 104591 & $\begin{array}{l}\text { Eicosanoid } \\
\text { ligand-binding receptors }\end{array}$ & $3.8 \mathrm{e}-02$ & 2 & 13 \\
\hline 23802 & $\begin{array}{l}\text { Mouse JAK2 binds human } \\
\text { common beta chain }\end{array}$ & $5.1 \mathrm{e}-04$ & 2 & 2 \\
\hline 89750 & Hemostasis & $1.5 e-03$ & 19 & 400 \\
\hline 33150 & Endogenous sterols & $3.4 \mathrm{e}-02$ & 2 & 13 \\
\hline 108993 & Vitamin B2 metabolism & $2.9 \mathrm{e}-03$ & 2 & 4 \\
\hline 111211 & $\begin{array}{l}\text { Stat5 tyrosine } \\
\text { phosphorylation }\end{array}$ & $4.9 e-03$ & 2 & 5 \\
\hline 115537 & $\begin{array}{l}\text { IL7ra is phosphorylated } \\
\text { on Y449 }\end{array}$ & $4.9 e-03$ & 2 & 5 \\
\hline 81332 & $\begin{array}{l}\text { Ubiquitination of } \\
\text { phospho-p27/p21 }\end{array}$ & $1.6 \mathrm{e}-02$ & 2 & 9 \\
\hline 107910 & $\begin{array}{l}\text { Synthesis, Secretion, and } \\
\text { Deacylation of Ghrelin }\end{array}$ & $2.0 e-02$ & 2 & 10 \\
\hline \multicolumn{5}{|c|}{ [Down-regulated Genes] } \\
\hline 92778 & Axon guidance & $3.9 e-06$ & 26 & 353 \\
\hline 95727 & Myogenesis & $4.9 e-02$ & 2 & 13 \\
\hline 90528 & Signaling by VEGF & 4.7e-04 & 4 & 14 \\
\hline 100071 & $\begin{array}{l}\text { Integrin cell surface } \\
\text { interactions }\end{array}$ & $7.1 \mathrm{e}-03$ & 9 & 123 \\
\hline 82568 & $\begin{array}{l}\text { PDGF binds to extracellular } \\
\text { matrix proteins }\end{array}$ & $3.6 \mathrm{e}-02$ & 4 & 45 \\
\hline 118126 & $\begin{array}{l}\text { I-Smad competes with } \\
\text { R-Smad1/5/8 for } \\
\text { type I receptor }\end{array}$ & $1.9 \mathrm{e}-02$ & 2 & 8 \\
\hline 91050 & $\begin{array}{l}\text { SOS phosphorylation and } \\
\text { dissociation }\end{array}$ & 7.3e-03 & 2 & 5 \\
\hline 112933 & Cell-Cell communication & $1.7 e-02$ & 8 & 118 \\
\hline 95483 & Metabolism of nitric oxide & 3.0e-02 & 2 & 10 \\
\hline 84093 & Ethanol oxidation & $1.1 \mathrm{e}-03$ & 3 & 8 \\
\hline 79841 & FMO oxidizes nucleophiles & $2.3 e-03$ & 2 & 3 \\
\hline 97703 & Apoptotic execution phase & $1.1 \mathrm{e}-02$ & 5 & 49 \\
\hline 107112 & Aquaporin-mediated transport & 8.0e-03 & 4 & 29 \\
\hline 84730 & $\begin{array}{l}\text { MAPK targets/ Nuclear events } \\
\text { mediated by MAP kinases }\end{array}$ & 5.0e-02 & 3 & 30 \\
\hline
\end{tabular}

*Reactome event accession number.

${ }^{\dagger}$ Event name according to the Reactome Database.

${ }^{\ddagger}$ Number of regulated genes in this model.

${ }^{5}$ Total number of genes involved in the event.

JAM: Junctional adhesion molecule, GPCR: G protein coupled receptors, JAK: Janus kinase, VEGF: Vascular endothelial growth factor, PDGF: platelet-derived growth factor, SOS: Son of Sevenless proteins, FMO: Flavin Monooxygenases, MAPK: mitogen-activated protein kinase, MAP: Mitogen-activated protein. 
Table 4 Quantitative PCR Validation of Microarray Expression data

\begin{tabular}{|c|c|c|c|}
\hline \multirow[t]{2}{*}{ Gene symbol } & \multirow[t]{2}{*}{ Gene Name } & \multicolumn{2}{|c|}{ Fold Change ( $P$ value) ${ }^{*}$} \\
\hline & & RT-PCR & Microarray \\
\hline$\overline{\text { Acvrl1 }}$ & $\begin{array}{l}\text { Activin A receptor, } \\
\text { type II-like } 1\end{array}$ & $0.7(0.07)$ & $0.7(0.05)$ \\
\hline Bmpr2 & $\begin{array}{l}\text { Bone morphogenic } \\
\text { protein receptor, type ॥ }\end{array}$ & $0.6(0.04)$ & $0.8(0.04)$ \\
\hline Eng & Endoglin & $0.5(0.05)$ & $0.7(0.05)$ \\
\hline $\mathrm{Ccl} 8$ & Chemokine ligand 8 & $14.0(0.06)$ & $10.3(0.04)$ \\
\hline Ccl9 & Chemokine ligand 9 & $9.5(0.03)$ & $11.4(0.02)$ \\
\hline Ear11 & $\begin{array}{l}\text { Eosinophil-associated, } \\
\text { ribonuclease A family, } \\
\text { member } 11\end{array}$ & $76.0(0.04)$ & $72.4(0.02)$ \\
\hline $\operatorname{lgj}$ & $\begin{array}{l}\text { Immunoglobulin } \\
\text { joining chain }\end{array}$ & $20.5(0.26)$ & $10.0(0.05)$ \\
\hline Mmp12 & Matrix metallopeptidase 12 & 104.6(0.05) & $46.1(0.02)$ \\
\hline Mmp13 & Matrix metallopeptidase 13 & $5.1(0.17)$ & $5.7(0.05)$ \\
\hline Mmp19 & Matrix metallopeptidase 19 & $3.1(0.05)$ & $2.9(0.05)$ \\
\hline Nos3 & $\begin{array}{l}\text { Nitric oxide synthase 3, } \\
\text { endothelial cell }\end{array}$ & $0.7(0.09)$ & $0.8(0.17)$ \\
\hline Pdgfa & $\begin{array}{l}\text { Platelet derived } \\
\text { growth factor, alpha }\end{array}$ & $0.7(0.01)$ & $0.8(0.07)$ \\
\hline Vegfa & $\begin{array}{l}\text { Vascular endothelial } \\
\text { growth factor A }\end{array}$ & $0.6(<0.01)$ & $0.7(0.04)$ \\
\hline $\mathrm{Gapdh}^{\dagger}$ & $\begin{array}{l}\text { Glyceraldehyde-3-phosphate } \\
\text { dehydrogenase }\end{array}$ & $1.0(<0.01)$ & $0.9(0.46)$ \\
\hline
\end{tabular}

*Fold change values are calculated by dividing the experimental group values by the control values. Statistical analyses were performed by non-paired t-tests ${ }^{+}$Gapdh was used as an internal control.

Rho- Associated Coiled-Coil-Forming Protein Kinase (ROCK) pathway [26,27], and the hypoxia response pathway $[23,24]$, and down-regulations of the transforming growth factor beta (TGFB) signaling pathway [16]. Both PDGF signaling pathway [25] and VEGF signaling pathway $[15,26]$ were found as those up-regulated in IPAH and down-regulated in this model. Interestingly, not detected was a pathway showing the reverse pattern.

Among these various pathways, we would focus on the Wnt/PCP pathway as the essential pathway of pathogenesis in IPAH because this pathway is presently known to be in the upper levels of hierarchical pathways regulating other related pathways [12-14]. Laumanns et al. reported that microarray analysis of lung tissue from patients with IPAH demonstrated the contribution of this pathway to the pathogenesis of IPAH [27]. It has been reported Wnt family of signaling proteins is essential for organ development in general, and lung morphogenesis in particular [44]. Especially, the PCP pathway signals through activation of the Rho/ROCK signaling pathway are implicated in cytoskeletal organization and epithelial cell polarity. In addition, this pathway has been shown to be required for normal lung development, and reports are beginning
Table 5 Events (reactions and/or pathways) and the expression patterns in IPAH and in our PAH model

\begin{tabular}{|c|c|c|c|}
\hline ID* & Event Name $^{\dagger}$ & $\mathrm{IPAH}^{\ddagger}$ & Present model \\
\hline map04630 & JAK/STAT signaling & Up & UP \\
\hline REACT_604 & Hemostasis & Up & Up \\
\hline GO:0030520 & $\begin{array}{l}\text { Estrogen receptor } \\
\text { signaling pathway }\end{array}$ & Up & Up \\
\hline GO:0007210 & $\begin{array}{l}\text { Serotonin receptor } \\
\text { signaling pathway }\end{array}$ & Up & Up \\
\hline GO:0001666 & Response to hypoxia & Up & Not identified \\
\hline map04310 & Wnt/PCP pathway & Up & Not identified \\
\hline REACT_19389 & ROCK activation by Rho & Up & Not identified \\
\hline REACT_16888 & Signaling by PDGF & Up & Down \\
\hline REACT_12529 & Signaling by VEGF & Up & Down \\
\hline GO:0042981 & $\begin{array}{l}\text { Regulation of } \\
\text { apoptotic process }\end{array}$ & Up/Down & Down \\
\hline REACT_12034 & Signaling by BMP & Down & Down \\
\hline REACT_6844 & Signaling by TGF beta & Down & Not identified \\
\hline
\end{tabular}

*Accession number of Reactome, KEGG, and GO.

${ }^{\dagger}$ Event name according to the Reactome, KEGG, and GO Database. ‡Expression pattern of biological molecules associated with the event in lung tissue obtained from patients with IPAH in previously published reports JAK/STAT: Janus kinase-signal transducer and activator of transcription, PCP: planar cell polarity, ROCK: Ras Homolog- Associated Coiled-Coil-Forming Protein Kinase, Rho: Ras Homolog, PDGF: Platelet-derived growth factor, VEGF: Vascular endothelial growth factor, BMP: Bone morphogenetic protein, TGF: Transforming growth factor.

to emerge of links between PCP pathways and lung disease [45]. Besides IPAH, PCP gene expression changes were observed within isolated pulmonary vasculature in patients with pulmonary fibrosis. Studies of patients with IPAH have shown significant up-regulation of PCP signaling [27] and down-regulation of TGFB signaling [16]. Investigations have also shown inhibition of canonical Wnt signaling by PCP ligands [45], crosstalk between canonical Wnt signaling and TGFB signaling [46], and recruitment of both canonical and non-canonical Wnt pathways are required in BMP2 mediated angiogenesis in human pulmonary artery endothelial cells [47]. A part of results from the present study, no change of pathways around this system can support that altered interaction between the canonical Wnt pathway and the TGFB signaling pathway play an essential role for human disease and further clarification is expected of the role of the PCP pathway in the pathogenesis of IPAH. On the other hand, some previous reports conducted human disease reported the Rho/ROCK signaling pathway is also activated, but it is known that many other stimuli can activate this system [48]. An activation of this pathway may conduct to smooth muscle cell proliferation in pulmonary artery [49], we wish to understand this event as secondary episode to alteration in PCP signaling pathways.

Although, the details in the mechanism is unclear, various factors (e.g., Hypoxia, inflammation, and shear 
Table 6 Summarized events (reactions and/or pathways) and the expression patterns in previously rat models

\begin{tabular}{|c|c|c|c|c|}
\hline $\mathrm{ID}^{*}$ & Event Name $^{\dagger}$ & Hypoxia-induced model $^{\ddagger}$ & Hypoxia-induced model $^{\S}$ & MCT-induced model ${ }^{\natural}$ \\
\hline map04630 & JAK/STAT signaling & Not identified & Not identified & Not identified \\
\hline REACT_604 & Hemostasis & Down & Up/Down & Up/Down \\
\hline GO:0030520 & Estrogen receptor signaling pathway & Up & Not identified & Down \\
\hline GO:0007210 & Serotonin receptor signaling pathway & Up/Down & Not identified & Down \\
\hline GO:0001666 & Response to hypoxia & Up/Down & Up & Down \\
\hline map04310 & Wnt/PCP pathway & Not identified & Not identified & Not identified \\
\hline REACT_19389 & ROCK activation by Rho & Up & Not identified & Down \\
\hline REACT_16888 & Signaling by PDGF & Up & Up/Down & Down \\
\hline REACT_12529 & Signaling by VEGF & Not identified & Not identified & Down \\
\hline GO:0042981 & Regulation of apoptotic process & Up/Down & Not identified & Up/Down \\
\hline REACT_12034 & Signaling by BMP & Up/Down & Not identified & Not identified \\
\hline REACT_6844 & Signaling by TGF beta & Up & Up & Up \\
\hline
\end{tabular}

${ }^{*}$ Accession number of Reactome, KEGG, and GO.

${ }^{\dagger}$ Event name according to the Reactome, KEGG, and GO Database.

${ }^{\ddagger}$ Hypoxia-induced rat models reported by Moreno-Vinasco et al [31].

${ }^{\S}$ Hypoxia-induced rat models reported by Kwapiszewska et al [32].

"MCT-induced rat models reported by Vaszar et al [33].

JAK/STAT: Janus kinase-signal transducer and activator of transcription, PCP: planar cell polarity, ROCK: Ras Homolog- Associated Coiled-Coil-Forming Protein Kinase, Rho: Ras Homolog, PDGF: Platelet-derived growth factor, VEGF: Vascular endothelial growth factor, BMP: Bone morphogenetic protein, TGF: Transforming growth factor, MCT: Monocrotaline.

stress) are known as the inducer of growth factors such as VEGF and PDGF [50,51]. Accordingly, their activation may not be essential because they usually play at the lower level of hierarchical pathways, which are activated by many sorts of stimuli.

\section{Conclusion}

Discrepancy in gene expression pattern between this model and the human disease previously reported suggests that activation of Rho/ROCK signaling via Wnt/PCP signaling plays an essential role in pathogenesis of IPAH.

\section{Additional file}

Additional file 1: Expression pattern of biological molecules in lung tissue obtained from patients with IPAHand related pathways.

\section{Competing interests}

Dr. Shibuya reports receiving research grants from Pfizer Inc., Janssen Pharmaceutical K.K., Dainippon Sumitomo Pharma Co., Astellas Pharmaceutical Company, Taiho Pharmaceutical, and Pola pharma. All authors declare that they have no conflict of interest.

\section{Authors' contributions}

KS designed the study, participated in the data collections and the interpretation of the results, and drafted the manuscript as the first author. YO carried out the experiments and the histopathological evaluation and revised the manuscript as an equal contributor of the present study. EO, HK, and MS carried out the experiments and participated in the data collections. HN and TI carried out the histopathological evaluation and performed the statistical analysis. DS, NT, and TN carried out the histopathological evaluation and prepared figures. MW participated in the interpretation of the results, revised the manuscript, and gave final approval to the manuscript as a corresponding author. TS conceptualized the study and advised the first author on pulmonary hypertension as a clinical doctor. KK conceptualized the study and helped to draft the manuscript. KS conceptualized and designed the study, carried out histopathological and statistical evaluation, and revised the manuscript as a last author. All authors contributed to conceptualizing and writing this study. Furthermore, all authors read and approved the final manuscript.

\section{Acknowledgements}

This work was supported by the Health Science Research Grants for Research on Emerging and Re-emerging Infectious Diseases (H22-Shinkou-Ippan-8 and H23-Shinkou-Ippan-018) from the Ministry of Health, Labor and Welfare of Japan, a grant from the Strategic Basis on Research Grounds for Nongovernmental Schools at Heisei 20th from the Ministry of Education, Culture, Sports, Science and Technology of Japan to KS, a grant from the Strategic Research Foundation Grant-aided Project for Private schools at Heisei 23rd from Ministry of Education, Culture, Sports, Science and Technology of Japan to KS, 2011-2015, a Toho University project grant \#23-19, 21, and 28, Yokohama Foundation for Advancement of Medical Science grant to YO and MS, Dr Yanase's grant of Toho University Medical School to YO, and Grant-inAid for Young Scientists B from the Ministry of Education, Culture, Sports, Science and Technology of Japan (KAKENHI, \#24790364) to YO.

\section{Author details}

'Department of Surgical Pathology, Toho University School of Medicine, 6-11-1 Omori-Nishi, Ota-Ku, Tokyo 143-8541, Japan. ²Department of Pediatrics, Toho University Omori Medical Center, 6-11-1 Omori-Nishi, Ota-Ku, Tokyo 143-8541, Japan. ${ }^{3}$ Department of Pathogenic Fungi, Medical Mycology Research Center, Chiba University, 1-8-1 Inohana, Chuo-ku, Chiba 260-8673, Japan. ${ }^{4}$ Department of Microbiology, Immunology and Molecular Genetics, University of Kentucky College of Medicine, 800 Rose Street, Lexington, KY 40536, USA. ${ }^{5}$ Department of Pathology, National Institute of Infectious Diseases, 1-23-1 Toyama, Shinjuku-ku, Tokyo 162-8640, Japan. ${ }^{6}$ Department of Dermatology, Peking University First Hospital, NO.7, Xishiku Street, Xicheng District, Beijing 100034, China.

Received: 12 August 2012 Accepted: 13 November 2012 Published: 17 November 2012

\section{References}

1. Simonneau G, Robbins IM, Beghetti M, Channick RN, Delcroix M, Denton CP, Elliott CG, Gaine SP, Gladwin MT, Jing ZC, Krowka MJ, Langleben D, Nakanishi N, Souza R: Updated clinical classification of pulmonary hypertension. J Am Coll Cardiol 2009, 54:S43-S54. 
2. Peacock AJ, Murphy NF, McMurray JJ, Caballero L, Stewart S: An epidemiological study of pulmonary arterial hypertension. Eur Respir $J$ 2007, 30:104-109.

3. Sankelo M, Flanagan JA, Machado R, Harrison R, Rudarakanchana N, Morrell N, Dixon M, Halme M, Puolijoki H, Kere J, Elomaa O, Kupari M, Räisänen-Sokolowski A, Trembath RC, Laitinen T: BMPR2 mutations have short lifetime expectancy in primary pulmonary hypertension. Hum Mutat 2005, 26:119-124.

4. Newman JH, Trembath RC, Morse JA, Grunig E, Loyd JE, Adnot S, Coccolo F, Ventura C, Phillips JA 3rd, Knowles JA, Janssen B, Eickelberg O, Eddahibi S, Herve P, Nichols WC, Elliott G: Genetic basis of pulmonary arterial hypertension: current understanding and future directions. J Am Coll Cardiol 2004, 43:33S-39S.

5. Firth AL, Mandel J, Yuan JX: Idiopathic pulmonary arterial hypertension. Dis Model Mech 2010, 3:268-273.

6. Ochiai E, Kamei K, Watanabe A, Nagayoshi M, Tada Y, Nagaoka T, Sato K, Sato A, Shibuya K: Inhalation of Stachybotrys chartarum causes pulmonary arterial hypertension in mice. Int J Exp Pathol 2008, 89:201-208.

7. Black JA, Dean TR, Foarde K, Menetrez M: Detection of Stachybotrys chartarum using rRNA, tri5, and beta-tubulin primers and determining their relative copy number by real-time PCR. Mycol Res 2008, 112:845-851.

8. Black JA, Foarde KK: Comparison of four different methods for extraction of Stachybotrys chartarum spore DNA and verification by real-time PCR. J Microbiol Methods 2007, 70:75-81.

9. Groshong SD, Tomashefski JF Jr, Cool CD: Pulmonary Hypertensive vascular Disease. In Dail and Hammar's pulmonary pathology. Volume 1. 3rd edition. Edited by Tomashefski JF Jr. New York: Springer; 2008:1032-1087.

10. Pepper SD, Saunders EK, Edwards LE, Wilson CL, Miller CJ: The utility of MAS5 expression summary and detection call algorithms. BMC Bioinforma 2007, 8:273.

11. Maere S, Heymans K, Kuiper M: BiNGO: a Cytoscape plugin to assess overrepresentation of gene ontology categories in biological networks. Bioinformatics 2005, 21:3448-3449.

12. Croft D, O'Kelly G, Wu G, Haw R, Gillespie M, Matthews L, Caudy M, Garapati P, Gopinath G, Jassal B, Jupe S, Kalatskaya I, Mahajan S, May B, Ndegwa N, Schmidt E, Shamovsky V, Yung C, Birney E, Hermjakob H, D'Eustachio P, Stein L: Reactome: a database of reactions, pathways and biological processes. Nucleic Acids Res 2011, 39:D691-D697.

13. Barrell D, Dimmer E, Huntley RP, Binns D, O'Donovan C, Apweiler R: The GOA database in 2009-an integrated gene ontology annotation resource. Nucleic Acids Res 2009, 37:D396-D403.

14. Kanehisa M, Goto S, Furumichi M, Tanabe M, Hirakawa M: KEGG for representation and analysis of molecular networks involving diseases and drugs. Nucleic Acids Res 2010, 38:D355-D360.

15. Rajkumar R, Konishi K, Richards TJ, Ishizawar DC, Wiechert AC, Kaminski N, Ahmad F: Genomewide RNA expression profiling in lung identifies distinct signatures in idiopathic pulmonary arterial hypertension and secondary pulmonary hypertension. Am J Physiol Heart Circ Physiol 2010, 298:H1235-H1248.

16. Fantozzi I, Huang W, Zhang J, Zhang S, Platoshyn O, Remillard CV, Thistlethwaite PA, Yuan JX: Divergent effects of BMP-2 on gene expression in pulmonary artery smooth muscle cells from normal subjects and patients with idiopathic pulmonary arterial hypertension. Exp Lung Res 2005, 31:783-806.

17. Sanchez O, Marcos E, Perros F, Fadel E, Tu L, Humbert M, Dartevelle P, Simonneau G, Adnot S, Eddahibi S: Role of endothelium-derived CC Chemokine ligand 2 in idiopathic pulmonary arterial hypertension. Am J Respir Crit Care Med 2007, 176:1041-1047.

18. Masri FA, Xu W, Comhair SA, Asosingh K, Koo M, Vasanji A, Drazba J, AnandApte B, Erzurum SC: Hyperproliferative apoptosis-resistant endothelial cells in idiopathic pulmonary arterial hypertension. Am J Physiol Lung Cell Mol Physiol 2007, 293:L548-L554.

19. Hecker M, Zaslona Z, Kwapiszewska G, Niess G, Zakrzewicz A, Hergenreider E, Wilhelm J, Marsh LM, Sedding D, Klepetko W, Lohmeyer J, Dimmeler S, Seeger W, Weissmann N, Schermuly RT, Kneidinger N, Eickelberg O, Morty RE: Dysregulation of the IL-13 receptor system a novel pathomechanism in pulmonary arterial hypertension. Am J Respir Crit Care Med 2010, 182:805-818.

20. Courboulin A, Paulin R, Giguère NJ, Saksouk N, Perreault T, Meloche J, Paquet ER, Biardel S, Provencher S, Côté J, Simard MJ, Bonnet S: Role for
miR-204 in human pulmonary arterial hypertension. J. Exp. Med 2011, 208:535-548.

21. Dewachter L, Adnot S, Fadel E, Humbert M, Maitre B, Barlier-Mur AM, Simonneau G, Hamon M, Naeije R, Eddahibi S: Angiopoietin/Tie2 pathway influences smooth muscle hyperplasia in idiopathic pulmonary hypertension. Am J Respir Crit Care Med 2006, 174:1025-1033.

22. Yu Y, Keller SH, Remillard CV, Safrina O, Nicholson A, Zhang SL, Jiang W, Vangala N, Landsberg JW, Wang JY, Thistlethwaite PA, Channick RN, Robbins IM, Loyd JE, Ghofrani HA, Grimminger F, Schermuly RT, Cahalan $M D$, Rubin $\sqcup$, Yuan JX: A functional single-nucleotide polymorphism in the TRPC6 gene promoter associated with idiopathic pulmonary arterial hypertension. Circulation 2009, 119:2313-2322.

23. Lepetit H, Eddahibi S, Fadel E, Frisdal E, Munaut C, Noel A, Humbert M, Adnot S, D'Ortho MP, Lafuma C: Smooth muscle cell matrix metalloproteinases in idiopathic pulmonary arterial hypertension. Eur Respir J 2005, 25:834-842

24. Eddahibi S, Humbert M, Fadel E, Raffestin B, Darmon M, Capron F, Simonneau G, Dartevelle P, Hamon M, Adnot S: Serotonin transporter overexpression is responsible for pulmonary artery smooth muscle hyperplasia in primary pulmonary hypertension. J Clin Invest 2001, 108:1141-1150.

25. Perros F, Montani D, Dorfmüller P, Durand-Gasselin I, Tcherakian C, Le Pavec J, Mazmanian M, Fadel E, Mussot S, Mercier O, Hervé P, Emilie D, Eddahibi S, Simonneau G, Souza R, Humbert M: Platelet-derived growth factor expression and function in idiopathic pulmonary arterial hypertension. Am J Respir Crit Care Med 2008, 178:81-88.

26. Do e Z, Fukumoto Y, Takaki A, Tawara S, Ohashi J, Nakano M, Tada T, Saji K, Sugimura K, Fujita H, Hoshikawa Y, Nawata J, Kondo T, Shimokawa H: Evidence for Rho-kinase activation in patients with pulmonary arterial hypertension. Circ J 2009, 73:1731-1739.

27. Laumanns IP, Fink L, Wilhelm J, Wolff JC, Mitnacht-Kraus R, Graef-Hoechst S, Stein MM, Bohle RM, Klepetko W, Hoda MA, Schermuly RT, Grimminger F, Seeger W, Voswinckel R: The noncanonical WNT pathway is operative in idiopathic pulmonary arterial hypertension. Am J Respir Cell Mol Biol 2009, 40:683-691.

28. Golpon HA, Geraci MW, Moore MD, Miller HL, Miller GJ, Tuder RM, Voelkel NF: HOX genes in human lung: altered expression in primary pulmonary hypertension and emphysema. Am J Pathol 2001, 158:955-966.

29. Stenmark KR, Meyrick B, Galie N, Mooi WJ, McMurtry IF: Animal models of pulmonary arterial hypertension: the hope for etiological discovery and pharmacological cure. Am J Physiol Lung Cell Mol Physiol 2009, 297:L1013-L1032.

30. Rabinovitch M: Cellular and molecular pathobiology of pulmonary hypertension conference summary. Chest 2005, 128:642S-646S.

31. Moreno-Vinasco L, Gomberg-Maitland M, Maitland ML, Desai AA, Singleton PA, Sammani S, Sam L, Liu Y, Husain AN, Lang RM, Ratain MJ, Lussier YA, Garcia JG: Genomic assessment of a multikinase inhibitor, sorafenib, in a rodent model of pulmonary hypertension. Physiol Genomics 2008, 33:278-291

32. Kwapiszewska G, Wilhelm J, Wolff S, Laumanns I, Koenig IR, Ziegler A Seeger W, Bohle RM, Weissmann N, Fink L: Expression profiling of lasermicrodissected intrapulmonary arteries in hypoxia-induced pulmonary hypertension. Respir Res 2005, 6:109.

33. Vaszar LT, Nishimura T, Storey JD, Zhao G, Qiu D, Faul JL, Pearl RG, Kao PN: Longitudinal transcriptional analysis of developing neointimal vascular occlusion and pulmonary hypertension in rats. Physiol Genomics 2004, 17:150-156.

34. Pestka JJ, Yike I, Dearborn DG, Ward MD, Harkema JR: Stachybotrys chartarum, trichothecene mycotoxins, and damp building-related illness: new insights into a public health enigma. Toxicol Sci 2008, 104:4-26.

35. Chida A, Shintani M, Nakayama T, Furutani Y, Hayama E, Inai K, Saji T, Nonoyama S, Nakanishi T: Missense mutations of the BMPR1B (ALK6) gene in childhood idiopathic pulmonary arterial hypertension. Circ J 2012, 76:1501-1508.

36. Shintani $M$, Yagi H, Nakayama T, Saji T, Matsuoka R: A new nonsense mutation of SMAD8 associated with pulmonary arterial hypertension. J Med Genet 2009, 46:331-337.

37. Price LC, Wort SJ, Perros F, Dorfmüller P, Huertas A, Montani D, CohenKaminsky S, Humbert M: Inflammation in pulmonary arterial hypertension. Chest 2012, 141:210-221.

38. Pfeifer AC, Timmer J, Klingmüller U: Systems biology of JAK/STAT signalling. Essays Biochem 2008, 45:109-120. 
39. Nicolls MR, Taraseviciene-Stewart L, Rai PR, Badesch DB, Voelkel NF: Autoimmunity and pulmonary hypertension: a perspective. Eur Respir J 2005, 26:1110-1118.

40. Cicalini S, Chinello P, Petrosillo N: HIV infection and pulmonary arterial hypertension. Expert Rev Respir Med 2011, 5:257-266.

41. Thenappan T, Shah SJ, Rich S, Gomberg-Maitland M: A USA-based registry for pulmonary arterial hypertension: 1982-2006. Eur Respir J 2007, 30:1103-1110

42. Maclean MR, Dempsie Y: The serotonin hypothesis of pulmonary hypertension revisited. Adv Exp Med Biol 2010, 661:309-322.

43. Johnson SR, Granton JT, Mehta S: Thrombotic arteriopathy and anticoagulation in pulmonary hypertension. Chest 2006, 130:545-552.

44. Pongracz JE, Stockley RA: Wnt signalling in lung development and diseases. Respir Res 2006, 7:15.

45. Yates LL, Dean CH: Planar polarity: a new player in both lung development and disease. Organogenesis 2011, 7:209-216.

46. Königshoff M, Eickelberg O: WNT signaling in lung disease: a failure or a regeneration signal? Am J Respir Cell Mol Biol 2010, 42:21-31.

47. de Jesus Perez VA, Alastalo TP, Wu JC, Axelrod JD, Cooke JP, Amieva M, Rabinovitch M: Bone morphogenetic protein 2 induces pulmonary angiogenesis via Wnt-beta-catenin and Wnt-RhoA-Rac1 pathways. J Cell Biol 2009, 184:83-99.

48. Buchsbaum RJ: Rho activation at a glance. J Cell Sci 2007, 120:1 149-1152.

49. Fukumoto Y, Matoba T, Ito A, Tanaka H, Kishi T, Hayashidani S, Abe K, Takeshita A, Shimokawa H: Acute vasodilator effects of a Rho-kinase inhibitor, fasudil, in patients with severe pulmonary hypertension. Heart 2005, 91:391-392.

50. Norrby K: Mast cells and angiogenesis. APMIS 2002, 110:355-371.

51. Chen L, Endler A, Shibasaki F: Hypoxia and angiogenesis: regulation of hypoxia-inducible factors via novel binding factors. Exp Mol Med 2009, 41:849-857.

doi:10.1186/1465-9921-13-103

Cite this article as: Shimodaira et al:: Gene expression analysis of a murine model with pulmonary vascular remodeling compared to endstage IPAH lungs. Respiratory Research 2012 13:103.

\section{Submit your next manuscript to BioMed Central and take full advantage of:}

- Convenient online submission

- Thorough peer review

- No space constraints or color figure charges

- Immediate publication on acceptance

- Inclusion in PubMed, CAS, Scopus and Google Scholar

- Research which is freely available for redistribution 